\title{
Contributions of a social technology from the perspective of men being sued for gender violence
}

\author{
Contribuições de uma tecnologia social na perspectiva de homens em processo judicial por violência de gênero
}

Contribuciones de una tecnología social a la perspectiva de los hombres en procedimientos judiciales de violencia de género

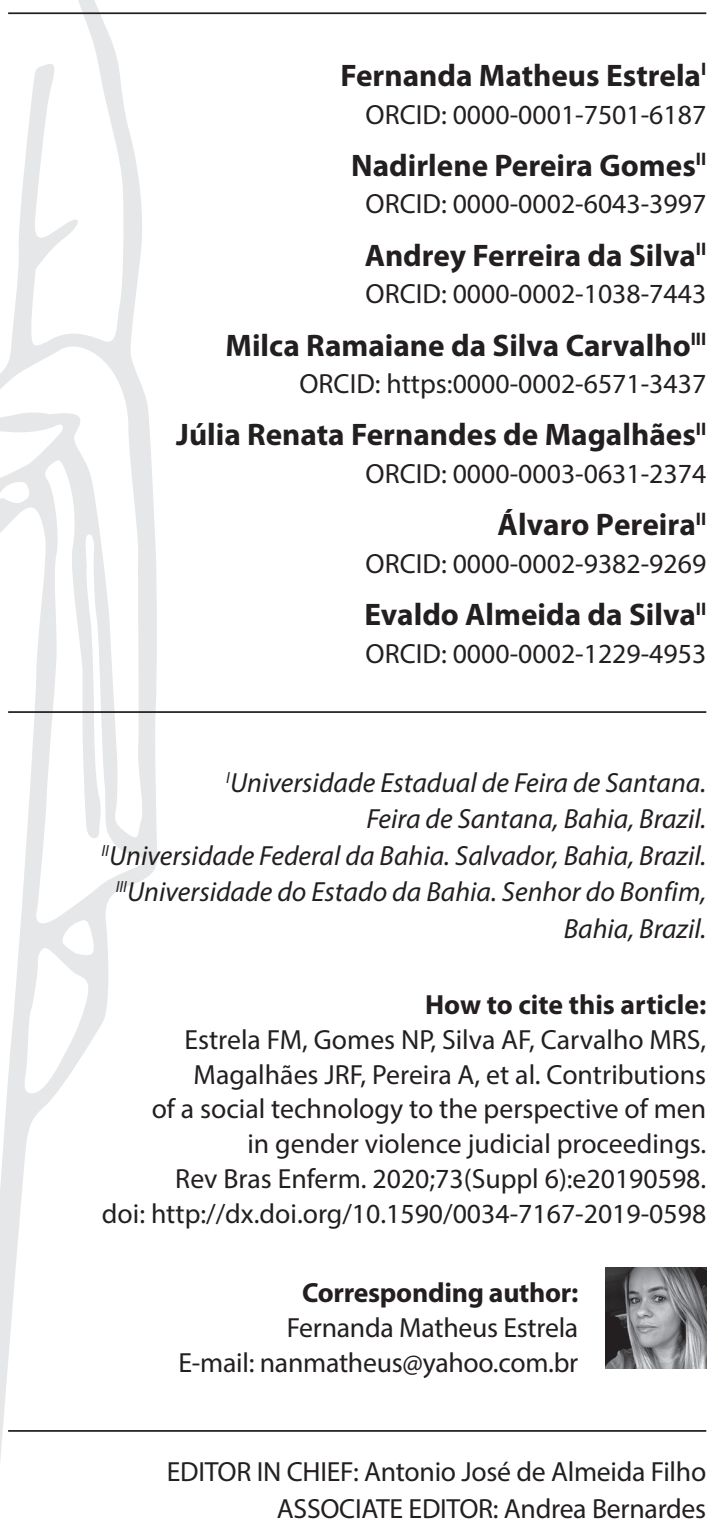

Submission: 08-12-2019

Approval: 04-24-2020

\section{ABSTRACT}

Objectives: to discover what were the contributions of the Reflexive Group from the perspective of men being sued by marital violence, who participated in a social technology. Methods: qualitative study, resulting from the evaluation stage of an action-research, based on the perspective of Critical Freedom and carried out with 44 men who were being sued in the Peace at Home Courts, in Salvador, Bahia, Brazil. Results: the discourses of men being sued for marital violence showed that the reflections enabled them to share their experiences; understand their attitudes as disrespectful, violent, and liable in criminal courts; elaborate of strategies for a harmonious marital life; and become multipliers as a result of their willingness to socialize the information and knowledge that emerged from their group. Conclusions: the study presents a successful experience of the participation of men in reflexive groups and is a precedent for the validation of this social technology.

Descriptors: Gender-Based Violence; Masculinity; Education; Men; Culturally Appropriate Technology.

\section{RESUMO}

Objetivos: conhecer as contribuições do Grupo Reflexivo na perspectiva de homens em processo criminal por violência conjugal que participaram de uma tecnologia social. Métodos: estudo com abordagem qualitativa, oriundo da fase de avaliação de uma pesquisa-ação, fundamentada na Perspectiva Crítico-Libertadora e realizada com 44 homens que respondiam a processos nas Varas de Justiça pela Paz em Casa, Salvador, Bahia, Brasil. Resultados: os discursos de homens em processo judicial por violência conjugal revelaram que os grupos reflexivos possibilitaram: o compartilhamento de suas vivências; a percepção de suas atitudes enquanto desrespeitosas, violentas e passíveis de responsabilização criminal; a formulação de estratégias para uma vida conjugal harmoniosa; e a formação de multiplicadores como resultado do desejo de socializar as informações e saberes que emergiram no grupo. Conclusões: o estudo apresenta a experiência exitosa da participação de homens em grupos reflexivos, sendo este um precedente para a validação dessa tecnologia social.

Descritores: Violência de Gênero; Masculinidade; Educação; Homens; Tecnologia Social.

\section{RESUMEN}

Objetivos: conocer las contribuciones del Grupo Reflexivo en la perspectiva de hombres en proceso criminal por violencia conyugal que participaron de una tecnología social. Métodos: estudio con abordaje cualitativo, oriundo de la fase de evaluación de una investigaciónacción, fundamentada en la Perspectiva Crítico-Libertadora y realizada con 44 hombres que respondían a procesos en las Jurisdicciones de Justicia por la Paz en Casa, Salvador, Bahia, Brasil. Resultados: los discursos de hombres en proceso judicial por violencia conyugal revelaron que los grupos reflexivos posibilitaron: el compartimiento de sus vivencias; la percepción de sus actitudes mientras irrespetuosas, violentas y pasibles de responsabilidad criminal; la formulación de estrategias para una vida conyugal harmoniosa; y la formación de multiplicadores como resultado del deseo de socializar las informaciones y saberes que emergieron en el grupo. Conclusiones: el estudio presenta la experiencia exitosa de la participación de hombres en grupos reflexivos, siendo esto un precedente para la validación de esa tecnología social.

Descriptores: Violencia de Género; Masculinidad; Educación; Hombres; Tecnología Social. 


\section{INTRODUCTION}

Considering the complexity and magnitude of marital violence, its roots in the social construction of gender and its serious implications for the life of a family, measures to prevent and confront this phenomenon are necessary. Among them, stand out the creation of spaces that facilitate the perception, by men, of their actions that are violent and, as a result, liable.

Data related to marital violence show the vulnerability of these women within their own houses. A research carried out with 1,102 Brazilians show that nearly one in every five has experienced some type of domestic or family violence, which is mostly carried out by their spouse ${ }^{(1)}$. Even in developed countries, such as the United States, England, and the United Kingdom, the rates of marital violence are high ${ }^{(2-3)}$, suggesting that this is a worldwide issue.

Studies also highlight the repercussions that living with marital violence has on women and on the development of their children. The damage to women include, according to researches carried out in South America and Africa, physical, mental, and social impairments: from physical damage, such as bruises, fractures, burns, and abortions, to the somatization of these experiences, which manifests through depressive and suicidal behaviors and may reflect on difficulties to socialize and enter the job market, the latter as a result of abandoning studies and/or of lacking qualification ${ }^{(4-7)}$. As for the children, studies show impairments in their physical (such as maxillofacial trauma) and mental health, since children in this situation tend to be more introspective, depressive, aggressive, and are more likely to have a lower school performance and use drugs $\mathrm{s}^{(4,7-8)}$.

With regards to the men, there is a gap in knowledge about the impact that marital conflicts have in their lives. That may be related to the predominance of studies about marital violence which are carried out from the perspective of women, since they are the ones who suffer the most its consequences. These can even result in femicide, a crime whose high rates reached 5.13 for each 100 thousand women in $2015^{(9)}$.

Considering the above, this study believes that a possible strategy is showing to the men the impacts of marital violence in their own lives. For this process to take place, it is essential to invest in researches carried out from their perspective. To this end, studies showed that preventive arrests due to marital violence led to mental disease, including sadness, low self-esteem, apathy, or depression, and to physical damage, such as alterations in gastric and sleeping patterns, headaches, tachycardia, and hypertension ${ }^{(10-11)}$. They also report that men tend to develop high blood pressure, gastritis, insomnia, lose contact with their children, and when they were caught in the act while committing their crimes, that can even lead them to be sexually assaulted by their cell mates, in addition to the difficulties of going back to the job market due to having been incarcerated ${ }^{(7)}$.

This context means that many actions are necessary to prevent and deal with the problem. These actions involve not only women, but also the other subjects in the relationship: the men. Considering the socially constitutional character of masculinity in our society, the complexity of the phenomena must also be considered. It has its roots in a male-centric society, which legitimates marital violence as it naturalizes the perception of women as submissive to men, the latter having the power and dominance in relationships ${ }^{(11)}$. As a result, considering that these roles and attributes are taught both to men and women, the creation of spaces where the deconstruction of gender stereotypes can happen and men can reflect on their actions is urgent, leading to an increased awareness and to the recognition of their accountability for their actions.

With this regard, it is worth highlighting the creation of Law 11.340/2006, a Brazilian piece of legislation known as law Maria da Penha. It recommends the creation of centers for the education and rehabilitation of violent offenders, and their inclusion in programs to recover and reeducate them through reflective, educational, and pedagogical activities ${ }^{(12)}$. With regards to the reeducation programs in Brazil, there are 19 recognized institutions with reflexive group methodologies ${ }^{(13-14)}$. Their effective contributions to the changes in the behavior of men, however, are hardly ever made public, especially with regards to familial and marital relations.

Starting with the assumption that these spaces favor the change in male behavior towards a life without violence, and can contribute for the diminution of the corrosive characteristics of this problem - those that can have serious repercussions in the lives of people involved and even impair the humane development of the children - , the following question was raised: What are the contributions of the Reflection Group from the perspective of men being sued for marital violence who were part of a social technology? In this study, the term "social technology" refers to a replicable culturally appropriate technology ${ }^{(15)}$ that was developed in interactions with the community, representing an effective solution for social transformation and for the struggle against marital violence.

\section{OBJECTIVES}

To know the contributions of the Reflection Group from the perspective of men being sued by marital violence, who participated in the social technology.

\section{METHODS}

\section{Ethical aspects}

In accordance to Resolution No. 466/12 from the National Health Council, the project was approved by the Research Ethics Committee of the Nursing School of the Universidade Federal da Bahia, under legal opinion No. 877.905/2014. This research respected all ethical aspects prescribed by all guidelines and regulation norms for researches involving human beings. To maintain the confidentiality of information and the anonymity of collaborators, the interviews were carried out in a private room in the institution. The men were identified using an alphanumeric code: the letter " $\mathrm{H}$ " followed by a number $(\mathrm{H} 1, \mathrm{H} 2 \ldots \mathrm{H} 13)$.

\section{Type of study}

This is an action research with a qualitative approach, stemming from the doctorate thesis "Social Technology for Men to Prevent Marital Violence". This research, in turn, is associated to the umbrella project "Confronting marital violence in the Single Health System: social technologies involving women, men, and 
primary healthcare professionals", which is funded by the Agency for the Support of Research from the State of Bahia (FAPESB).

The expression "action research" refers, here, to a research that has an empirical base and aims to function as an action in society. The objective of this research is associated to actions aimed at preventing marital violence. More specifically, it is worth mentioning that the action research is structured in the following stages: diagnoses, planning of actions, execution of actions, evaluation, and data analysis ${ }^{(16)}$. This study used data from the evaluation stage.

\section{Methodological procedures}

The participants were, at first, informed by the judges of the local court to participate on the Reflection Group (RG), developed by the researchers of the Group Vid@ to create a social technology to prevent marital violence. It stands out that the social technology is an innovative methodological model. It is constructivist and involves collective participation, aiming at transforming the subjects - in this case, the men who are in a situation of marital violence. This technology was carried out using the action-research, a method that aims to prevent, minimize, and/or solve a certain collective interest problem by proposing actions related to it.

\section{Study Setting}

The umbrella project in which this work is involved was developed with men that, during research, were being sued for marital violence in the 1st and 2nd Peace at Home Courts in Salvador, Bahia, Brazil.

\section{Data sources}

Regarding the actions developed, they followed the RG as a communication workshop model. It is used to construct and produce theoretical and practical knowledge in an active and reflective way. The RGs were developed in five cycles, which took place from January 2016 to December 2017, and counted on the participation of 44 men. Each cycle was made up of eight meetings which took place once a week, in consecutive weeks, with the exception of the last one, which aimed to evaluate the results and took place at least one month after the others. The results of this study were based on the evaluation stage of the meetings, according to Chart 1.

Chart 1 - Thematic of Reflection Groups, by found

\begin{tabular}{|c|l|}
\hline DATE & THEME \\
\hline $1^{\text {st }}$ meeting & Presentation of the RG \\
\hline $2^{\text {nd }}$ meeting & The influence of the family in the formation of "I" \\
\hline $3^{\text {rd }}$ meeting & The social construction of gender inequality \\
\hline $4^{\text {th }}$ meeting & Masculinities and the formation of the "new man" \\
\hline $5^{\text {th }}$ meeting & Men's health and encouragement to self-care \\
\hline $6^{\text {th }}$ meeting & Perceiving violent actions \\
\hline $7^{\text {th }}$ meeting & The peaceful resolution of conflicts \\
\hline $8^{\text {th }}$ meeting & RG evaluation \\
\hline Note: $R G$ - Reflection Group.
\end{tabular}

The researchers, aiming to provide an in-depth discussion of the themes addressed, needed to go themselves in-depth in the content available on the subject in scientific literature. They also discussed with experts on the field and used the knowledge found to organize the sequence of the discussions and conduct the workshops. The systematization of these workshops was carried out considering the work of theoreticians who discuss family, gender, masculinity, pacific conflict resolution, healthcare, as well as the epistemological principles of Freire, which value the knowledge brought by the subjects through dialogue, seeking to overcome limit situations.

\section{Collection and organization of data}

The data collection process was carried out considering the evaluation stage, which was carried out by two researchers in an individual interview.

This stage of the action research, namely, the "evaluative" stage, was developed one year after the participation in the RG. This time was deemed necessary for the participants to assimilate the experience and, therefore, report on their availability for changing the way in which they relate to their relatives, especially the women.

This stage involved 13 men who were part of the RG and accepted participating in the evaluation stage. They were all in accordance to the inclusion criteria, which was having missed, at most, one of the eight meetings. The 44 men who were part of one of the 5 RGs were contacted via telephone. 39 were found and invited to participate in this stage of the research. From them, 26 refused participation claiming personal reasons, especially the lack of time.

The data collection process of the evaluation took part through an interview, carried out by two researchers and directed by a semi-structured script that contained closed questions to classify the collaborators (self-declared skin color, age, educational level, marital status, type of household, occupation and work situation, and whether, after 12 months, there was any recidivism of the behavior related to the marital violence lawsuit they had been subjected to in the Peace at Home Justice Courts in Salvador, Bahia, Brazil) and two guiding questions on the possibilities of using RGs for personal change. The questions were: What were the contributions of the RG to your life? Was there any change in your behavior and in your attitudes as a husband, father, and son after participating in the reflective group?

The interviews lasted from 30 to 45 minutes and took place one year after the RGs were finished, that is, from December 2016 to June 2018. The interviews were conducted in the State Educational Center Magalhães Neto (CAE), near the 1st Judicial Court.

\section{Data analysis}

For the systematization and organization of data, the Discourse of the Collective Subject was used, according to Lefevre and Lefevre. This method was used in all stages of the research action. It makes it possible to describe opinions, beliefs, and social presentations of collectivities, aiming to preserve the nature of the individuals. It is a proposal of rebuilding the collective entity, who is offering an 
opinion in the form of a person in the first person of the singular. To do so, the following stages were respected: 1) Transcription of the statements; 2) Analysis of the material collected, in which the methodological figures "Central Ideas" (CI), and their respective Key Expressions (KE) were extracted; 3) Composition, based on the Cls and KEs, of the many synthesized discourses, written in the first person from the KEs and Cls, forming what is called the Discourse of the Collective Subject ${ }^{(17)}$.

The results were based on reflections about daily life, which in turn were supported by theoretical frameworks on gender, masculinity, themes discussed in the groups, and on the theoretical framework of Paulo Freire. The critical-freedom perspective of Freire is seen as pertinent to direct these activities, since it proposes a dialogic education, which raises concerns and reinforces the reflections and the autonomy of subjects, offering, with the themes discussed, the possibility of changing conducts to achieve a violence-free family and marital relationships.

\section{RESULTS}

\section{Subject characterization}

The 13 men being sued for marital violence, who participated in the evaluation stage of the research action, were from 25 to 67 years of age. Most were self-declared black (10), with complete elementary education (9), and four of them stated to have complete higher education. Only one lives with a new wife; six live alone, and six live with near relatives (parents and/or siblings). Most of them stated to live in a house they own (11) and had a job (7) in professions such as guard, waiter, nursing technician, driver, public worker, and entrepreneur.

Regarding marital aspects, most participants were single (8), and 2 of them stated that they were in relationships. The others were divorced (2) or widowers (1). With regards to recidivism of marital violence lawsuits in the Peace at Home Justice Courts from Salvador, which was evaluated 12 years after the last RG meeting, none of the men who were interviewed and participated in the social technology had new marital violence cases with their partners.

\section{The creation of a space to share experiences}

The discourse of the men sued for marital violence showed that the RG was a space for dialogue and for sharing experiences, despite an initial perception of the space as a coercive one, especially due to the judicial obligation of being there. The perception of the men changed towards valuing the educational aspect of the group as they started to realize that the group was a space to hear and to be heard, a type of experience they considered uncommon during criminal procedures.

At first, I was afraid of participating, because I thought it would be a coercive environment, especially since it was a mandatory activity. Through the workshops, I started to notice its importance as a space for dialog, especially because we are not heard at the police station or during the hearings. Here, we had our questions clarified, we expressed our opinions and we had the opportunity of sharing our experiences with other men who were going through the same judicial problems. $(\mathrm{H} 2, \mathrm{H} 5, \mathrm{H} 6, \mathrm{H} 9, \mathrm{H} 11, \mathrm{H} 14, \mathrm{H} 17, \mathrm{H} 19$, $\mathrm{H} 22, \mathrm{H} 29, \mathrm{H} 31, \mathrm{H} 35, \mathrm{H} 41, \mathrm{H} 43$ )

\section{Perception the men had about their violent actions}

The discourse of the men also showed that the actions developed in the RG enabled them to perceive that their behaviors towards their wives were supported on violent and disrespectful actions, and therefore, criminally liable under law Maria da Penha. This change in their perspective took place after discussions and reflections about the many ways in which violence can be expressed, making it possible both to deconstruct the idea that it is only connected to physical aggression, and to recognize it in actions such as controlling, cursing, pushing, and non-consensual sexual acts.

Before participating in the group, I thought that only slaps, punches, and kicks were violence. During our relation, I thought I was the owner of my partner, up to the point where I wouldn't let her work, and demanded that she stayed home taking care of our kids. [...] I would pinch her, push her, curse her, and force sex without her consent. I thought these were common actions in a marital relation. I didn't see them as forms of violence. In the group, I started to understand that women should be respected and have their rights protected, that they can work and study. [...] I got to know that there are many forms of sexual violence: psychological, moral, patrimonial, sexual. I also learned that these other expressions of violence are liable under Law Maria da Penha. $(\mathrm{H} 1, \mathrm{H} 3, \mathrm{H} 4 . \mathrm{H} 10$, $\mathrm{H} 13, \mathrm{H} 15, \mathrm{H} 16, \mathrm{H} 20, \mathrm{H} 25, \mathrm{H} 27, \mathrm{H} 30, \mathrm{H} 34, \mathrm{H} 40, \mathrm{H} 42, \mathrm{H} 44$ )

\section{The constitution of strategies for peaceful conflict resolution}

The RG also was relevant to formulate strategies for a harmonious marital life, since it enabled men to rethink the way in which they would react to conflict, seeking better ways to deal with them instead of resorting to violence. The participants mentioned strategies for healthy coexistence, based on the valuing of family, on the sharing of chores and on mutual respect, and especially, based on dialog.

Before being in the reflective group, I acted impulsively and violently. I was in constant conflict with my partner for reasons that, oftentimes, could have been avoided. The group taught me the importance of valuing my family, of helping my partner in household chores, and in the creation of our children; it also taught me to respect opinions, even if they are different from mine and that, in a conflict, I should avoid arguments, and try to have a conversation and find a consensus between the parts. When these strategies have no effect, separation is a possibility. $(\mathrm{H1}, \mathrm{H} 3, \mathrm{H7}$, $\mathrm{H} 10, \mathrm{H} 15, \mathrm{H} 16, \mathrm{H} 18, \mathrm{H} 22, \mathrm{H} 23, \mathrm{H} 26, \mathrm{H} 27, \mathrm{H} 28, \mathrm{H} 30, \mathrm{H} 31, \mathrm{H} 32$, H33, H36, H37, H40, H41, H42, H43, H44)

\section{Forming multipliers}

The RG was also a setting for the formation of multipliers, due to the spontaneous desire of the men in the group to share their experiences, which they expressed through the socialization of the information and knowledge that emerged in the group. These conducts broaden the scope of the proposal of the project and increase its potential, which is preventing marital violence. 
Participating in the $R G$ was very important, since l learned and understood many things. Whenever I have the chance, I tell my friends about the elements that trigger marital violence, its expressions, the repercussions of experiencing this situation for men, women and children, the strategies to solve conflicts peacefully, and how important gender equality is in our society. $(\mathrm{H} 2, \mathrm{H} 4, \mathrm{H} 6, \mathrm{H} 8, \mathrm{H} 12$, $\mathrm{H} 13, \mathrm{H} 17, \mathrm{H} 19, \mathrm{H} 21, \mathrm{H} 24, \mathrm{H} 25, \mathrm{H} 29, \mathrm{H} 34, \mathrm{H} 35, \mathrm{H} 38, \mathrm{H} 40, \mathrm{H} 44)$

\section{DISCUSSION}

The spaces for discussion promoted by the RG brought forth themes related to the importance of the family in the formation of a subject, to the impacts of gender inequality in gender and marital relations, to the expressions of violence against women, to the practices of self-care, and to the methods of peaceful conflict resolution, together with the epistemological principles of Freire, which value the knowledge brought by the subject and uses dialog as a tool.

The discourses of men being sued for marital violence showed that participating in the RGs made it possible for them to share their experiences in exchange for knowledge. Studies from Asia and South America also showed that men saw these groups as an important environment for listening and being listened to ${ }^{(13-14,18)}$. Epistemologically, the RG can be understood as a space for reflecting on the actions of one's daily life. The space was based on dialog, on constructivism, and on the interaction between individual and environment ${ }^{(19)}$. That is because these settings favor the establishment of the trust needed for people - for instance, men being sued by marital violence - to be able to expose their thoughts, anxieties, and doubts ${ }^{(14,20)}$.

It stands out that participants in this study reported not having the opportunity of expressing themselves in any other setting of the entire judicial process, which reinforces the importance of spaces for dialog, such as this one. Researches developed in Europe and South America also reiterate the relevance of these environments for discussion and reflection, highlighting that they gradually started being promoted to offer self-knowledge and the valuing of human subjectivities and experiences ${ }^{(13,21)}$.

Considering the discourses, it is possible to see that, in addition to the possibility of speaking openly on their experiences, and to getting to know the experiences of others who are going through similar lawsuits, the men also felt embraced, since they were treated with education and without being judged.

It is important to highlight that a national study pointed out that men who are indicted for marital violence, once they enter judicial-police services, felt treated as culprits for their crime too early. According to them, they are held accountable for their transgression of the law before investigation or judgment ${ }^{(22)}$. This early assumption of blame is against the presumption of innocence, the judicial principle according to which the accused is innocent until judged ${ }^{(22)}$. In our study, participants have shown a similar feeling. They understood that having to participate on the Reflexive Group was a coercive measure that assumed their guilt, since it was mandatory and took place before their process was concluded. For the men accused of marital violence, the suppression of their right to speak and the imposition of participation in educational activities before the lawsuit was concluded reflected the biased nature of Law Maria da Penha, which conceives males as, essentially, cruel beings ${ }^{(23)}$.

This context contributes for men to see this law as an instrument specifically created to punish males without minimally investigating the reliability of the statements given by women, instead of seeing it as tool aimed at curbing and preventing domestic and family violence against women ${ }^{(24)}$. A different perception was found by a study carried out in South America, which points out that methodologies of intervention, created together with men who were the perpetrators of violence, create spaces for reflection, dialog, and for the development of new skills, contributing for the social confrontation of violence-related social problems but not being seen as a punishment for the members of the group ${ }^{(25)}$.

On the other hand, it should be highlighted that, despite being resistant and distrusting the proposals of the RGs instituted by law, as the meetings progressed, participants started to abandon their initial fears they had. As a result, they opened a space for the process of re-signifying social gender constructions, based on the experience of being responsible for marital violence. Other successful experiences took place in groups of men accused of marital violence and can be found in studies from South America, Europe, and Asia ${ }^{(18,23)}$. During the process of mediation of the group, the team sought to value dialog, the experiences brought by the subjects, encouraging them to read their own world in a different way ${ }^{(20)}$.

This process of re-signifying their violent experiences was favored by the perception of these men that, for the first time, they were being heard with no judgment and having their statements valued. In addition, the encouragement to the reflection on the actions of the marital relationship made it possible to deconstruct the idea that violence is especially tied to physical aggression. That, in turn, made it possible to understand that there are many possible forms in which violence manifests itself, which are: physical, psychological, sexual, property-related, and moral. Considering that, the RG made it possible for participants to recognize previously naturalized marital conducts, which involved controlling, cursing, pushing, or non-consensual sex, as criminal actions, liable under Law Maria da Penha ${ }^{(12,26)}$. According to the assumptions of the pedagogy of freedom, the natural male perception on violence as a natural phenomenon can be understood based on the premise that neutrality is more comfortable, if not, more hypocritical, than seeing what is happening as unjust. Therefore, to overcome reality, a social deconstruction of gender is necessary, which is paramount to transform reality ${ }^{(20)}$.

This naturalization of marital violence reflects the historical legacy of patriarchy, which attributes a position of power to men, a position of dominance over women. This understanding is not only shared by men, but also by women, since it is a social construct. These conceptions are culturally ingrained not only in South America, but also in European and Asian countries, making it extremely difficult to deconstruct ${ }^{(11,18,23)}$. Studies carried out in South America also revealed a naturalized perception of males with regards to marital relations ${ }^{(27-28)}$. The RG considers the naturalized male perception with regards to violence, and that is why it seeks to connect its reflections to the importance of deconstructing gender inequalities which are learned during childhood and reproduced in adult life. The premises proposed by Paulo Freire must also be applied, since he advocates the struggle against any form of oppression, proposing an education based on ethics, that can promote dignity and foment the autonomy of subjects with regards to themselves and to the collective ${ }^{(20)}$. 
In Africa, the male population only recognized violence against women in its most damaging expressions, such as burns, choking, and lesions with cutting weapons or firearms ${ }^{(29)}$. It can be inferred that the social permissions related to violent practices against the female figure makes men feel that they are being unfairly treated, becoming outraged when a judicial complaint involves expressions of violence other than the physical one, as pointed out by studies carried out in South and North America ${ }^{(27,30)}$. This context reiterates yet again the importance of reflexive spaces that encourage symmetry in relations between men and women ${ }^{(14)}$, especially with regards to the perception of violent conducts.

Therefore, the RG was an environment that encouraged reflections on the importance of respect in interpersonal relations on the need of seeking, collectively, peaceful strategies to deal with marital issues. As a result, discussions were encouraged on the way in which the men used to react to conflict, and on how they could act to avoid the practice of violence. Among the strategies mentioned, was sharing the household chores with the woman. That corroborates a study carried out in Pernambuco, which evidenced the fact that these chores were not shared as one of the main triggers of marital conflict ${ }^{(31)}$. Considering this finding, the sharing of these activities between the members of the couple is a strategy for cases in which there is no conflict, and, as a result, there is no practice of violence.

Other strategies for the peaceful resolution of conflicts that emerged from this study are related to valuing family and having mutual respect, especially through dialog. Successful experiences with regards to this issue can be found in many places around the world. Scholars from North America, South America, and Asia have shown measures that go from dialog-based negotiation strategies, to the importance of putting oneself on the shoes of the other, so a harmonious relationship can be experienced ${ }^{(14,18,31)}$. A systematic revision, aimed at evaluating educational programs targeted at men who committed marital violence in 12 countries in Europe, pointed out that the methods of conflict resolution are also in the scope if reflection groups that address themes that encourage the practice of respect and the avoiding of violence in marriages ${ }^{(31-32)}$. It stands out that the immersion in the theme "How to solve conflicts peacefully" was essential to minimize violence in marriage.

Among the contributions of the $\mathrm{RG}$, the dissemination of the information that the participants learned together also stands out, since it transformed them in multipliers of knowledge. A study carried out in South America showed that the dissemination of knowledge by the students favors not only individual learning, but also the solution of the daily problems of a collectivity ${ }^{(32)}$. This posture, the sharing of knowledge adopted by the men, means that the objective of the group went beyond the results anticipated, which were preventing marital violence.

Therefore, it could be said that the RG has a positive impact not only in the life of participants, but also in that of those who coexist with them. By bringing the information learned to others, participants contribute for the prevention of violence against other women, which, as a result, leads to a diminution of the damage related to this health issue.

In this study, education is advocated as something that can disseminate and produce values that direct the lives of the subjects. It should contribute for a society that is freer and just, and to overcome the many forms that oppression and dominance take in our society, in the search for a violence-free life.

\section{Study limitations}

This study has limitations, since it does not compare men who participated in reflection groups to those who did not; however, it can be inferred that this intervention practice is related to the prevention of further marital violence events. This success can be inferred because the recidivism rates of marital violence in the courts evaluated, after 12 months since the last meeting of the RG in the base study, was lower than the one found in other national studies. In the case of the men who participated in the social technology and accepted being interviewed, this rate was zero. Another limitation of this study was the low number of men who accepted participating in the evaluation stage (one year after the RGs were carried out), using as a justification lack of time, changes in their telephone numbers, and the absence of judicial mandates - as those in Law Maria da Penha, which made participating in the Reflection Groups themselves mandatory.

\section{Contributions to the field}

Regarding educational actions, especially in regards to the practice of nursing, spaces for reflecting on gender and on the changing conducts within relationships stand out as necessities, in order to favor symmetric relations, which lead to a lower number of marital violence cases. In the meantime, nursing stands out, since it takes on a prominent role in the development and/or coordination of educational actions, especially those of prevention against health problems, as is violence. The workers from the field are also in a prominent position to establish articulations with other social spaces, such as the schools, through the Health in School Program (PSE). Therefore, it can contribute for deconstructing the RGs with the public of children and adolescents, encouraging the social construction of gender, and perhaps even allowing the construction of symmetric relations in the marital bonds of the future, thus aiding in the prevention of marital violence.

Also, nursing has a paramount role with regards to this type of assistance. In this RG process, an active listening significantly contributes, from the moment in which there is any willingness to listen to an individual, there is an interest in participating in the process of helping this individual. Therefore, it becomes possible to identify, through listening, the difficulties experienced by these men, to efficiently offer contributions in the attention of their needs.

In addition to the aforementioned contributions, the protagonism of the nursing researches with regards to the theoretical dimensions of their work also stands out. This showed the urgency of gender studies in the field, which would help to deal with issues related to gender reeducation.

\section{CONCLUSIONS}

This study showed that men being sued for marital violence considered that participating in a RG enabled them to have dialogs and to share experiences; to recognize their own actions in their marriage as disrespectful, violent, and liable in a criminal court; as well as to elaborate strategies for a harmonious marital life, based, 
especially, on dialog. In addition to these contributions, the RG also helped men to socialize the information and the knowledge they acquired in the group, becoming themselves agents for the change of society and co-responsible for the building of a society that is free, just, and equal for men and women.

Therefore, the contributions of the RG can change the lives of men. The groups show themselves as a transformative strategy that can be used with many different male populations, in order to - through reflections on themes such as family, gender, masculinity, self-care practices, and peaceful conflict resolution - prevent conflicts and violence.

Since these groups are classified as a light technology, thus having low cost, this method is financially and operationally viable, and can be replicated by other professionals from different fields and in different settings, with men from all sociocultural levels. Therefore, the contributions experienced in the RGs can subsidize the development of actions not only in the scope of courts for violent crimes, as mandated by Law Maria da Penha, but also in other social spaces, as those in education, health, and security, including businesses, schools, health services, and entire communities. It is also possible to direct them at men with no history of marital violence, especially adolescents.

\section{FUNDING}

The Foundation for Research Support in Bahia (FABESP).

\section{REFERENCES}

1. Senado Federal (BR). Datasenado. Secretaria de Transparência. Violência doméstica e familiar contra a mulher. Senado Federal: Brasília, 2015.

2. Hutt J. Letter from Minister for Finance and Government Business to the Chair of Finance Com. Llywodraeth Cymru Welsh Government [Internet]. 2016 [cited 2018 Oct 10]. Available from: http://www.senedd.assembly.wales/documents/s500002795/Letter\%20from\%20 Minister\%20for\%20Finance\%20and\%20Government\%20Business\%20to\%20the\%20Chair\%20of\%20Finance\%20Committee\%20-\%207\%20 Janua.pdf

3. National Center for Injury Prevention and Control. Preventing Intimate Partner Violence [Internet]. CDC, 2017 [cited 2018 Aug 4]. Available from: https://www.cdc.gov/violenceprevention/pdf/ipv-factsheet.pdf

4. Carneiro JB, Gomes NP, Estrela FM, Santana JD, Mota RS, Erdmann AL. Domestic violence: repercussions for women and children. Esc Anna Nery. 2017;21(4):e20160346. doi: 10.1590/2177-9465-ean-2016-0346

5. Romdhane FF, Ridha R, Cheour M. Violence sexuelle exercée sur les femmes en Tunisie. Encephale. 2018. doi: 10.1016/j.encep.2018.07.004

6. Lírio JGS, Gomes NP, Paixão GPN, Pereira Á, Magalhães JRF, Cruz MA, et al. Abuso intrafamiliar na infância de homens em processo criminal por violência conjugal. Acta Paul Enferm. 2018;31(4):423-9. doi: 10.1590/1982-0194201800059

7. Hegarty K, Tarzia L, Murray E, Valpied J, Humphreys C, Taft A, et al. Protocol for a randomised controlled trial of a web-based healthy relationship tool and safety decision aid for women experiencing domestic violence (I-DECIDE). BMC Public Health [Internet]. 2015[cited 2017 May 26];15(1):736. Available from: http://bmcpublichealth.biomedcentral.com/articles/10.1186/s12889-015-2072-z

8. Namy S, Carlson C, O'Hara K, Nakuti J, Bukuluki P, Lwanyaaga J, et al. Towards a feminist understanding of intersecting violence against women and children in the family. Soc Sci Med[Internet]. 2017[cited 2017 May 26];184(5):40-8. Available from: http://www.ncbi.nlm.nih. gov/pubmed/5737762

9. Souza ER, Meira KC, Ribeiro AP, Santos J, Guimarães RM, Borges LF, et al. Homicídios de mulheres nas distintas regiões brasileiras nos últimos 35 anos: análise do efeito da idade-período e coorte de nascimento. Cien. Saude Colet. 2017;22(9):2949-62. doi: 10.1590/1413-81232017229.12392017

10. Cecchetto F, Oliveira QBM, Njaine K, Minayo MCS. Violências percebidas por homens adolescentes na interação afetivo-sexual em dez cidades brasileiras. Interface - Comun Saúde Educ. 2016; 20(59):853-64. doi: 10.1590/1807-57622015.0082

11. Sousa AR, Pereira Á, Paixão GPN, Pereira NG, Campos LM, Couto TM. Repercussions of imprisonment for conjugal violence: discourses of men. Rev Latino-Am Enfermagem [Internet] 2016 [cited 2017 May 26];24(0). doi: 10.1590/1518-8345.1569.2847

12. Presidência da República (BR). Lei no 11.340, de 7 de Agosto de 2006. Cria mecanismos para coibir a violência doméstica e familiar contra a mulher, nos termos do § 80 do art. 226 da Constituição Federal, da Convenção sobre a Eliminação de Todas as Formas de Discriminação contra as Mulheres e da Convenção Interamericana para Prevenir, Punir e Erradicar a Violência contra a Mulher; dispõe sobre a criação dos Juizados de Violência Doméstica e Familiar contra a Mulher; altera o Código de Processo Penal, o Código Penal e a Lei de Execução Penal; e dá outras providências. Brasília: Diário Oficial da União; 2006.

13. Beiras A, Nascimento M. Homens e violência contra mulheres: pesquisa e intervenções no contexto brasileiro. Rio de Janeiro: Instituto Noos, 2017.

14. Billand J, Paiva VSF. Deconstructing gender expectations from a minority standpoint: how to enter into a dialogue with male perpetrators of violence against women? Cien Saude Colet. 2017;29(9):2979. doi: 10.1590/1413-81232017229.13742016

15. Estrela FM, Gomes NP, Pereira Á, Paixão GPN, Silva AF, Sousa AR. Tecnologia social de prevenção da violência conjugal: o Grupo Vid@ em ações com homens. Rev Esc Enferm USP. 2020;54:e03545. doi: 10.1590/s1980-220x2018040803545

16. Thiollent M. Fundamentos e desafios da pesquisa-ação: contribuições na produção dos conhecimentos interdisciplinares. In: Toledo RF, Jacobi PR. (Org.). A pesquisa-ação na interface da saúde, educação e ambiente: princípios, desafios e experiências interdisciplinares. São Paulo: Annablume; 2012, p. 19-39. 
17. Lefevre F, Lefevre AMC. Discourse of the collective subject: social representations and communication interventions. Texto Contexto Enferm. 2014;23(2):502-7. doi: 10.1590/0104-07072014000000014

18. Chan KL, Emery CR, Fulu E, Tolman RM, Ip P. Association among father involvement, partner violence, and paternal health: UN multi-country cross-sectional study on men and violence. Am J Prev Med. 2017;52(5):671-9. doi: 10.1016/j.amepre.2016.12.017

19. Barreiros GF, Morato HTP. O encontro reflexivo como possibilidade de intervenção clínica em instituição educacional e grupo comunitário. Educ Pesqui. 2017;43(3):799-814. doi: 10.1590/s1517-9702201703150878

20. Freire P. Pedagogia da Autonomia: saberes necessários à prática educativa. 45 ed. Rio de janeiro: Paz e Terra, 2010

21. Zondi NB, Mbuli TJ. Just when we thought we were producing fine young men. Literator. 2016;37(1). doi: 10.4102/lit.v37i1.1160

22. Diário da República (PT). Resolução do Conselho de Ministros n.o 102/2013 - V Plano Nacional de Prevenção e Combate à Violência Doméstica e de Género. 1. a série — N.o 253 - 31 de dezembro de 2013. 2013

23. Toneli MJF, Beiras A, Ried J. Homens autores de violência contra mulheres: políticas públicas, desafios e intervenções possíveis na América Latina e Portugal. Rev Ciências Humanas [Internet] 2017[cited 2018 Nov 18];51(1):174. Available from: https://periodicos.ufsc.br/index.php/ revistacfh/article/view/2178-4582.2017v51n1p174

24. Escanciano SR, Caldas M. Cidadania e violência de gênero nas mulheres trabalhadoras: reflexões à luz do sistema jurídico espanhol e brasileiro. Rev Lei Conpedi [Internet] 2016 [cited 2018 Nov 18];1(5):136-66. Available from: https://doaj.org/article/8d8713de799b4356a50f104494bcfcbb

25. Neves ALM, Silva FA, Silva IR, Santos TS, Calegare FPP. Análise das metodologias de intervenção psicossocial em grupo de homens autores de violência conjugal. Rev Ártemis [Internet]. 2017 [cited 2018 Nov 18];23(1). Available from: https://periodicos.ufpb.br/ojs/index.php/ artemis/article/view/35787

26. Amaral LBM, Vasconcelos TB, Sá FE, Silva ASR, Macena RHM. Violência doméstica e a Lei Maria da Penha: perfil das agressões sofridas por mulheres abrigadas em unidade social de proteção. Rev Estud Fem. 2016;24(2):521-40. doi: 10.1590/1805-9584-2016v24n2p521

27. Paixão GPN, Pereira A, Gomes NP, Sousa AR, Estrela FM, Silva Filho URP, et al. Naturalization, reciprocity and marks of marital violence: male defendants' perceptions. Rev Bras Enferm. 2018;71(1):178-84. doi: 10.1590/0034-7167-2016-0475

28. Razera J, Mosmann CP, Falcke D. The Interface Between Quality and Violence in Marital Relationships. Paid (Ribeirão Preto). 2016; 26(63):719. doi: 10.1590/1982-43272663201609

29. Abramsky T, Devries KM, Michau L, Nakuti J, Musuya T, Kiss L, et al. Ecological pathways to prevention: How does the SASA! community mobilization model work to prevent physical intimate partner violence against women? BMC Public Health [Internet] 2016 [cited 2016 May 5];16(1):339. Available from: http://bmcpublichealth.biomedcentral.com/articles/10.1186/s12889-016-3018-9

30. Jewkes R, Flood M, Lang J. From work with men and boys to changes of social norms and reduction of inequities in gender relations: a conceptual shift in prevention of violence against women and girls. Lancet [Internet] 2015 [cited 2016 Jul 19];385(9977):1580-9. Available from: http://www.ncbi.nlm.nih.gov/pubmed/25467578

31. Holanda ER de, Holanda VR de, Vasconcelos MS de, Souza VP de, Galvão MTG. Fatores associados à violência contra as mulheres na atenção primária de saúde. Rev Bras Promoç Saúde [Internet] 2018; 31(1):1-9. Available from: http://periodicos.unifor.br/RBPS/article/view/6580

32. Moreno CG, Hegarty K, D'Oliveira AFL, McLain JK, Colombini M, Feder G. The health-systems response to violence against women. Lancet [Internet] 2015; 385(9977):1567-79. Available from: http://linkinghub.elsevier.com/retrieve/pii/S0140673614618377 